\title{
Selection of Candidate Fish Species for Farming in the Bay of Guaratuba, Brazil
}

\author{
Jean-Luc Bouchereau*1 ${ }^{*}$, Paulo T. Chaves ${ }^{2}$ and Jean-Jacques Albaret ${ }^{3}$ \\ ${ }^{1}$ Marine and Continental Hydrobiology Laboratory, UMR-CNRS 5556: Lagoon Ecosystems: biological \\ organisation and functionning; University of Montpellier II, cc093, Eugène Bataillon Place, F-34095, Montpellier \\ cedex 5, France. ${ }^{2}$ Laboratory of Ichtyology, Zoology Department, Federal University of Paraná, Curitiba, CP \\ 19020, 81531-990, Brazil. ${ }^{3}$ IRD-Montpellier; Marine and Continental Hydrobiology Laboratory, UM2, cc 093, \\ Eugène Bataillon Place, F-34095, Montpellier cedex 5, France.
}

\begin{abstract}
An inventory of the maximum length (ML) reached by 57 species of fishes living in the mangrove of Guaratuba, Brazil, was undertaken with an aim to evaluate the relationship between the ecosystem and the size of individuals. For each of these species, the maximum length found in the region were compared with those available in existing literature. The majority of populations presented individuals whose length reached at least 40\% than the known maximum length for the species, although only $19.3 \%$ were longer than $300 \mathrm{~mm}$ in absolute value. Population of the other species were represented only by individuals either in their initial development phases, or reduced length as compared to the maximum length known elsewhere for the same species. In this mangrove, species having the largest relative size are generally those that had the smallest absolute length. Proposed is use of an index LR (maximum observed lengths/maximum available lengths) as a tool for description and comparison of fish assemblages. Observations of the maximum size make possible the pre-selection of 12 species for breeding tests. In combining the biological, technical and commercial parameters, the pre-selection retains as primordial the following species: Centropomus parallelus, Centropomus undecimalis, Menticirrhus americanus and Micropogonias furnieri.
\end{abstract}

Key words: Maximum length; Selection; Fish; Aquaculture; Mangrove.

\section{INTRODUCTION}

During the last few years in Brazil, both the public and those at the governmental level have recognized the importance of aquaculture development (Borghetti, 1996). The national fishing supplying, either industrial or artisanal, remains irregular mainly because of the seasonality of exploitable fish resources. The production provided by aquaculture could allow the partial regulation of the market. However this activity is still little developed in Brazil as aquaculture production occupies only the $33^{\text {th }}$ international rank in 1995. That is the reason why the Ministry of Agriculture planned to launch programs aiming specially to develop the production of aquatic organisms, particularly that of aquaculture.

This study was conduced in the Guaratuba Bay, a subtropical ecosystem of $45 \mathrm{~km}^{2}$ situated at the south of Brazil $\left(25^{\circ} 52^{\prime} \mathrm{S} ; 48^{\circ} 39^{\prime} \mathrm{W}\right)$. The objective was to select species for fish culture in characterizing those reaching a sufficient commercial size and showing the best potentialities for rearing tests. First of all, it is necessary to consider that every paralic ecosystem (lagoons and estuaries) is currently considered as an environment playing a nursery role and rich in small-sized fish. This reduces the welcome and the maintenance of species whose individuals have an important length. Moreover, for some of them this environment is likely to cause a growth rate reduction (Frisoni

\footnotetext{
* Author for correspondence
} 
et al., 1984), particularly sedentary species occupying confined zone. This leads to the "lagoonar very small size the coastal characteristic", evoked in several works (Kiener, 1978; Guelorget \& Perthuisot, 1983), that involves semi enclosed ecosystems aptitude to favor the fish growth.

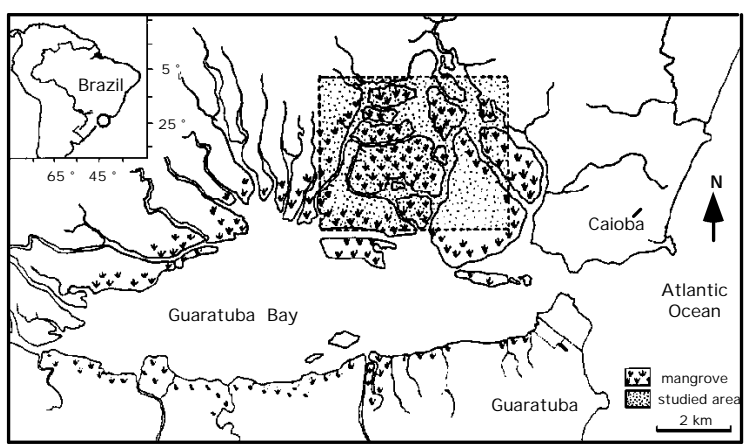

Figure 1. Sampling places in the Guaratuba Bay, Brazil (2552'S; 48³9'W).

One can consider that the dominance of small size fishes in any assemblage occupying a coastal ecosystem is the result of both associations. Although individuals of some populations attain a very large length, juveniles and sub adults are always the most numerous, which, consequently, favors the smallest lengths in the structure of their population. Populations of several species that frequent the system are exempt of large-sized individuals. The exclusive presence of reduced length individuals can be explained at the following levels: 1 . specific, if the individuals belong to species whose maximum size is naturally reduced; 2 . populational, if the populations to which they belong, in the mangroves present a slower and/or limited growth when compared with that met in same species populations in other ecosystems; 3 . ecophase, if the ecosystem only welcomes the life cycle initial stages of the individuals of these populations.

Obviously these reasons are not mutually exclusive to each other, and it is theoretically probable that several of them are acceptable to explain the composition of some assemblage. In our present study, we planned therefore to analyze maximum length reached by fishes occupying the mangrove of Guaratuba in order to show for each species the possible limiting factors which could explain the size reduction. In addition to pre-selection of species for farming purpose, attributes of size have also been considered according to Legendre \& Albaret's recommendations (1991).

\section{METHODS}

Sixty species of fishes recorded by Chaves \& Corrêa (1998) in the mangrove part of the Guaratuba Bay, Brazil $\left(25^{\circ} 52^{\prime} \mathrm{S} ; 48^{\circ} 39^{\prime} \mathrm{W}\right)$ were used in this study (Fig. 1). Monthly samples were collected by experimental fishing from July 1993 to February 1997 (except May 1995). The main engine used was the benthic trawl (20mm stretched mesh), but during the first two months, the sweep net and the tow seine (mesh size between 40 and $120 \mathrm{~mm}$ ) were also used. In addition to taxonomic identification, biometry and biological individual analysis were undertaken. For comparison, the available data analysis on the maximum length known for these species according to works of Figueiredo (1977), Figueiredo \& Menezes (1978), Figueiredo \& Menezes (1980), Menezes \& Figueiredo (1980), Menezes \& Figueiredo (1985) and Cervigón et al. (1992) were used. For this purpose, several references concerning each present species in the region were examined. When at least two of them presented differences as compared to the maximum length observed for a given species and a given region, the species closest to the populations of the southern region of Brazil (Guaratuba Bay) were taken as reference. When lengths (in $\mathrm{mm}$ ) quoted in the literature were inferior to the maximum observed length in the Guaratuba Bay, this last was considered as the maximum available length.

From these data for each species, LR index, the report between the maximum observed length (MOL) in the Bay and that available (MAL) in the literature was calculated: $\mathrm{LR}=\mathrm{MOL} / \mathrm{MAL}$.

In prospect of a commercial application to aquaculture, $300 \mathrm{~mm}$ was considered as the limit length between small and large size fishes. Then, to estimate the occurrence of adult individuals in the region, the threshold at 0.400 for LR was arbitrarily fixed as indicative of minimum value for the presence of adults in the 
population studied. Indeed, this values is

plausible

because Table 1. Code of species studied in the mangrove of Guaratuba; MOL: maximum observed length between 1993 and 1997; MAL: maximum available length and code of the literature reference. LR: length report MOL/MAL. Gr: group to which belongs each species, according to the proposed classification previously. The correspondence between codes and names of species can be consulted in Appendix; clear-grey: species less recommended; dark-grey: rather recommended species.

\begin{tabular}{|c|c|c|c|c|c|c|c|c|c|c|c|}
\hline Species & MOL & MAL & Source & LR & Gr & Species & MOL & MAL & Source & LR & $\mathbf{G r}$ \\
\hline ACLI & 174 & 230 & 2 & 0.757 & A2 & HACL & 166 & 170 & 1 & 0.976 & A1 \\
\hline ARRH & 241 & 350 & 1 & 0.689 & $\mathrm{~B}$ & HIRE & 80 & 180 & $1 *$ & 0.444 & A2 \\
\hline BARO & 200 & 350 & 1 & 0.571 & B & ISPA & 215 & 250 & 1 & 0.860 & A1 \\
\hline BASO & 125 & 165 & $1 *$ & 0.758 & A 2 & LALA & 267 & 600 & 1 & 0.445 & B \\
\hline CAHI & 215 & 1000 & 1 & 0.215 & $\mathrm{C}$ & LYGR & 241 & 270 & 1 & 0.893 & A1 \\
\hline CALA & 190 & 800 & 1 & 0.238 & $\mathrm{C}$ & MEAM & 375 & 500 & 1 & 0.750 & D \\
\hline CASP & 244 & 300 & 1 & 0.813 & A1 & MELI & 110 & 450 & 1 & 0.244 & $\mathrm{C}$ \\
\hline CEED & 157 & 166 & 2 & 0.946 & A1 & MIFU & 348 & 600 & 1 & 0.580 & D \\
\hline CEPA & 304 & 600 & 1 & 0.507 & $\mathrm{D}$ & MUCU & 298 & 450 & 1 & 0.662 & B \\
\hline CEUN & 298 & 1000 & 1 & 0.298 & $\mathrm{C}$ & MUGA & 162 & 450 & 1 & 0.360 & $\mathrm{C}$ \\
\hline CHCH & 147 & 300 & 1 & 0.490 & $\mathrm{~A} 2$ & NEBA & 241 & 1000 & 1 & 0.241 & $\mathrm{C}$ \\
\hline CHFA & 170 & 900 & 1 & 0.189 & $\mathrm{C}$ & OPOG & 167 & 300 & 1 & 0.557 & A2 \\
\hline CHSP & 192 & \# & - & - & - & ORRU & 155 & 400 & 1 & 0.388 & $\mathrm{C}$ \\
\hline CIAR & 190 & \# & - & - & - & PABR & 242 & 300 & 1 & 0.807 & A1 \\
\hline CISP & 153 & 200 & 2 & 0.765 & A 2 & PEHA & 174 & 174 & 1 & 1.000 & A1 \\
\hline CYAC & 285 & 1090 & 2 & 0.261 & $\mathrm{C}$ & POCO & 210 & 250 & 1 & 0.840 & A1 \\
\hline CYLE & 435 & 600 & 1 & 0.725 & D & POSA & 310 & 1000 & 1 & 0.310 & D \\
\hline DAVO & 224 & 450 & 1 & 0.498 & B & PRPU & 156 & 400 & 2 & 0.390 & $\mathrm{C}$ \\
\hline DIRA & 205 & 260 & 2 & 0.788 & A2 & RHPE & 575 & 1000 & 1 & 0.575 & D \\
\hline DIRH & 205 & 400 & 1 & 0.513 & B & RYRA & 156 & 190 & $1 *$ & 0.821 & A1 \\
\hline EPIT & 300 & 2700 & 1 & 0.111 & $\mathrm{C}$ & SCLU & 355 & 1200 & 1 & 0.296 & D \\
\hline EPNI & 148 & 1200 & 1 & 0.123 & $\mathrm{C}$ & SEVO & 200 & 400 & 1 & 0.500 & B \\
\hline ETCR & 125 & 200 & 2 & 0.625 & A2 & SPTE & 330 & 330 & 3 & 1.000 & D \\
\hline EUAR & 145 & 300 & 1 & 0.483 & A 2 & STHI & 80 & \# & - & - & - \\
\hline EUBR & 195 & 400 & 1 & 0.488 & B & STRA & 172 & 180 & 1 & 0.956 & A1 \\
\hline EUGU & 150 & 250 & 1 & 0.600 & A2 & SYFO & 284 & 430 & 2 & 0.660 & B \\
\hline EUME & 227 & 227 & 3 & 1.000 & A1 & SYTE & 186 & 230 & 2 & 0.809 & A1 \\
\hline GEGE & 357 & 357 & 3 & 1.000 & $\mathrm{D}$ & TRCA & 257 & 600 & 2 & 0.428 & B \\
\hline GELU & 288 & 370 & 2 & 0.778 & B & TRLE & 950 & 1500 & 2 & 0.633 & D \\
\hline GYOC & 440 & 520 & 1 & 0.846 & D & TRPA & 180 & 180 & 3 & 1.000 & A1 \\
\hline
\end{tabular}

\# : MAL not found in the literature

CODE OF MAL SOURCE:

(1): Figueiredo 1977; Figueiredo \& Menezes 1978; Figueiredo \& Menezes 1980; Menezes \& Figueiredo 1980; Menezes \& Figueiredo 1985.

$(1 *)$ : Same authors as above. However here, authors mention that MAL cited is for the maximum length obtained in their sample, and not to the maximum one known in the region.

(2): Cervigón et al. 1992.

(3): As after the references consulted, MAL value is less important than that found for Guaratuba, this one is considered as maximum for the species.

it is close to the ratio: mean length at first maturity/available length, calculated with 4 species from Guaratuba: Stellifer rastrifer $=0.53$ (Coelho et al., 1985), Isopisthus parvipinnis= 0.43 (Coelho et al., 1988), Micropogonias furnieri $=0.50$ (Haimovici \& Umpierre, 1996), Menticirrhus americanus $=0.35$ (AlvitresCastillo, 1986). Among littoral brazilian fish (Perez-Lizama \& Vazzoler, 1993): L50/L $\infty=$ 1.29-0.29logL $\infty$ and MOL of Guaratuba species, the ratio $\mathrm{L} 50 / \mathrm{L} \infty$ varied around 0.40 .

\section{RESULTS}

\section{Characterization of maximum size of individuals}

According to the literature, the maximum available length of 57 studied species (Table 1) varied between 165 (Batygobius soporator) and $2700 \mathrm{~mm}$ (Epinephelus itajara). MAL values of Citharichthys arenaceus, Stephanolepis hispidus and Chylomicterus spinosus were not found. The most represented $(17.5 \%) 100 \mathrm{~mm}$ size 


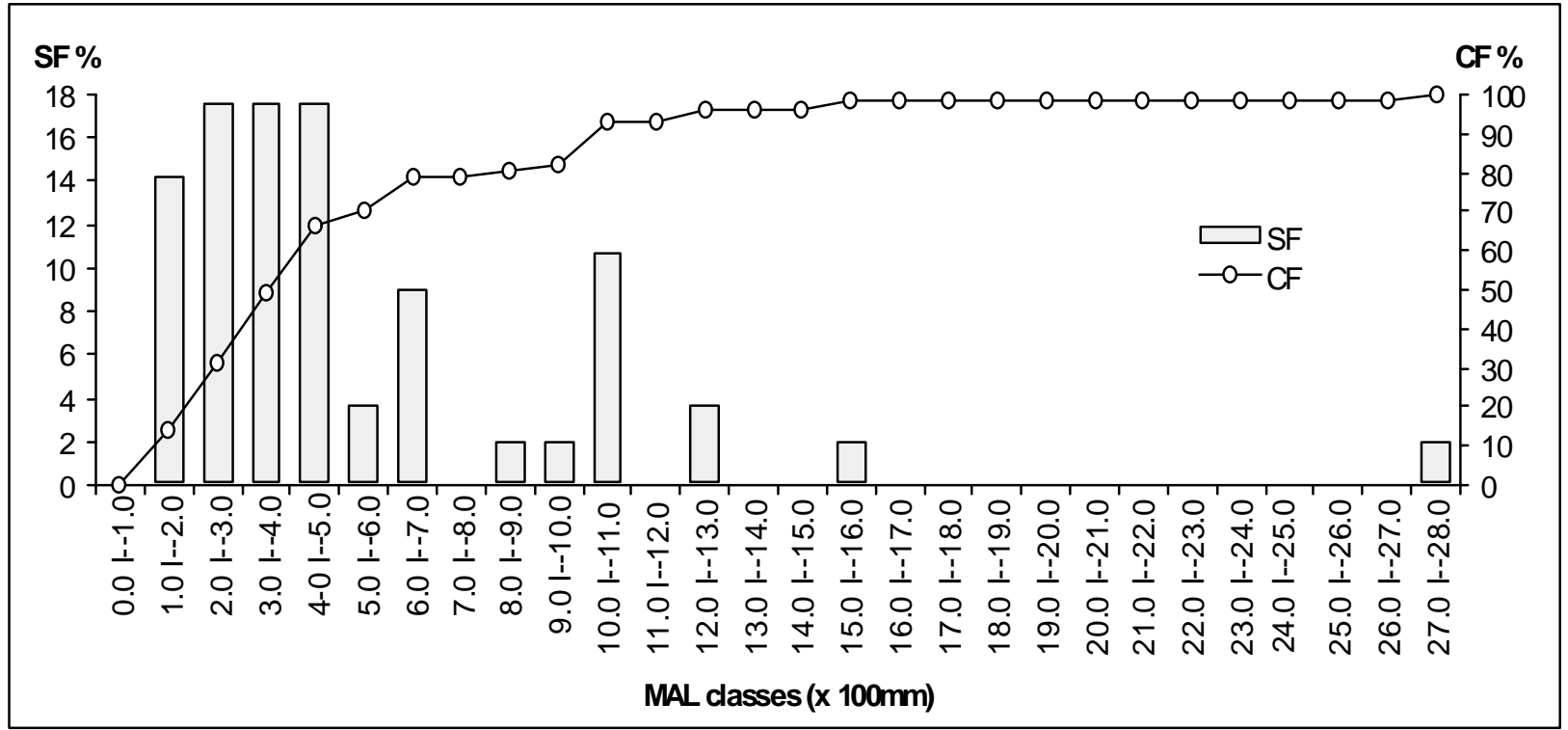

Figure 2. Simple (SF) and cumulative (CF) frequency distributions of the percentage of species occupying each maximum available length (MAL) in $\mathrm{mm}$.

2); $31.5 \%$ of total have a MAL below $300 \mathrm{~mm}$, and $49 \%$ below $400 \mathrm{~mm}$ (Fig. 2). The range of LR values varied from 0.11 (E. itajara) to 1.00 (5 species) (Fig. 3). The highest percentages of species (14\%) were found in LR classes 0.410.50, 0.81-0.90 and 0.91-1.00 (Fig. 4); $24.6 \%$ of species had a LR below 0.41 , and $50.9 \%$ below 0.61 .

\section{Classification of species according to their maximum length}

The highest LR values were generally associated with species showing a low MAL. In the 100$199 \mathrm{~mm}$ size class the mean LR was 0.86 ; the mean LR then decreased until the 400-499mm size class (Fig. 5). In the next class, the mean LR increased up to 0.80 , then decreased in the $1200-1299 \mathrm{~mm}$ size class. The noticeable exceptionally high LR (0.63) in the 1500-1599 size class corresponded to the species Trichiurus lepturus. It is a great ichtyophagous predator with a large locomotion capacity, that only passes through occasionally in the inner part of the Bay. In the highest class of MAL (2700$2799 \mathrm{~mm}$, E. itajara), the LR was the lowest: 0.11 (Fig. 5). The regression that associates these two variables is expressed by the relationship: $\mathrm{LR}=23.82 \cdot \mathrm{MAL}^{-0.63}(\mathrm{n}=57 ; \mathrm{r}=0.77)$.

If one considered the threshold at $300 \mathrm{~mm}$ in length and LR values, the species studied could be classified in the 4 different groups, A, B, C and D (Fig. 6; Table 1). This classification allowed, in the case of the absence of a large specimen missing of one species, to find an explanation at the specific, populational or ecophase levels.

GROUP A - Small size species, MAL not exceeding $300 \mathrm{~mm}$.

Subgroup A1 - 13 species whose LR was between 0.80 and 1.00. Adult individuals could therefore be found in the mangrove. The absence 


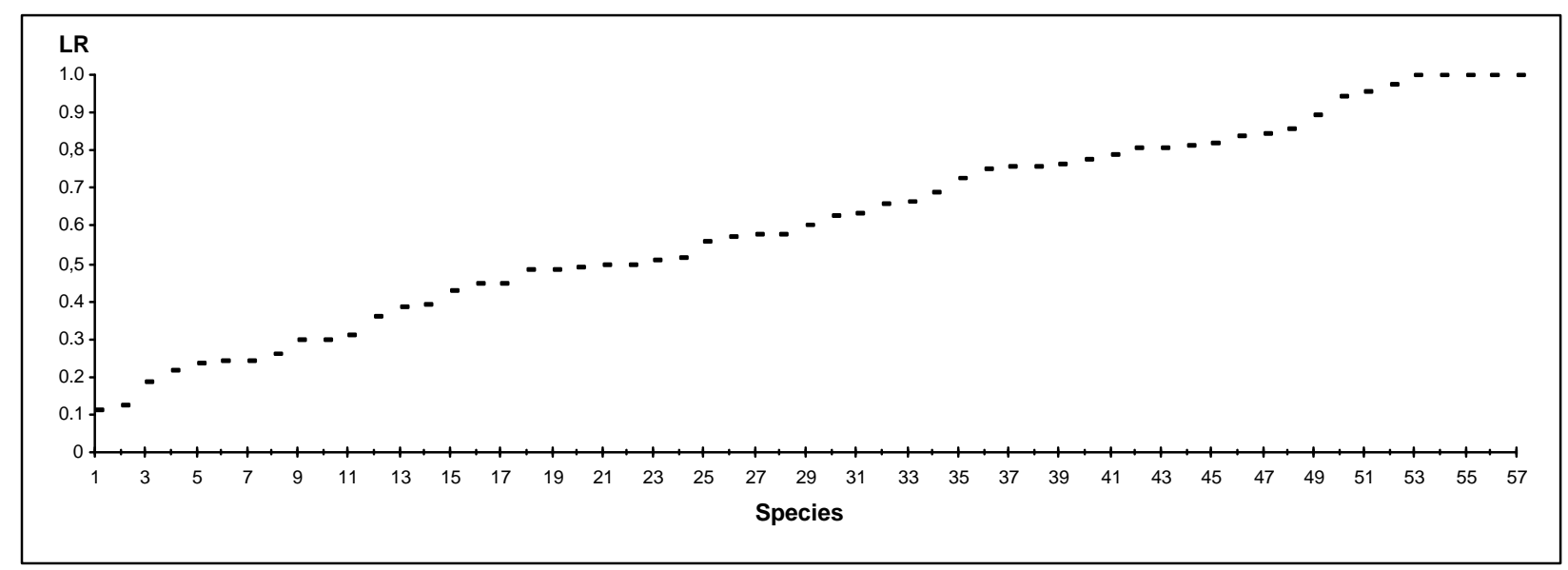

Figure 3. Distribution of LR values of the species studied.

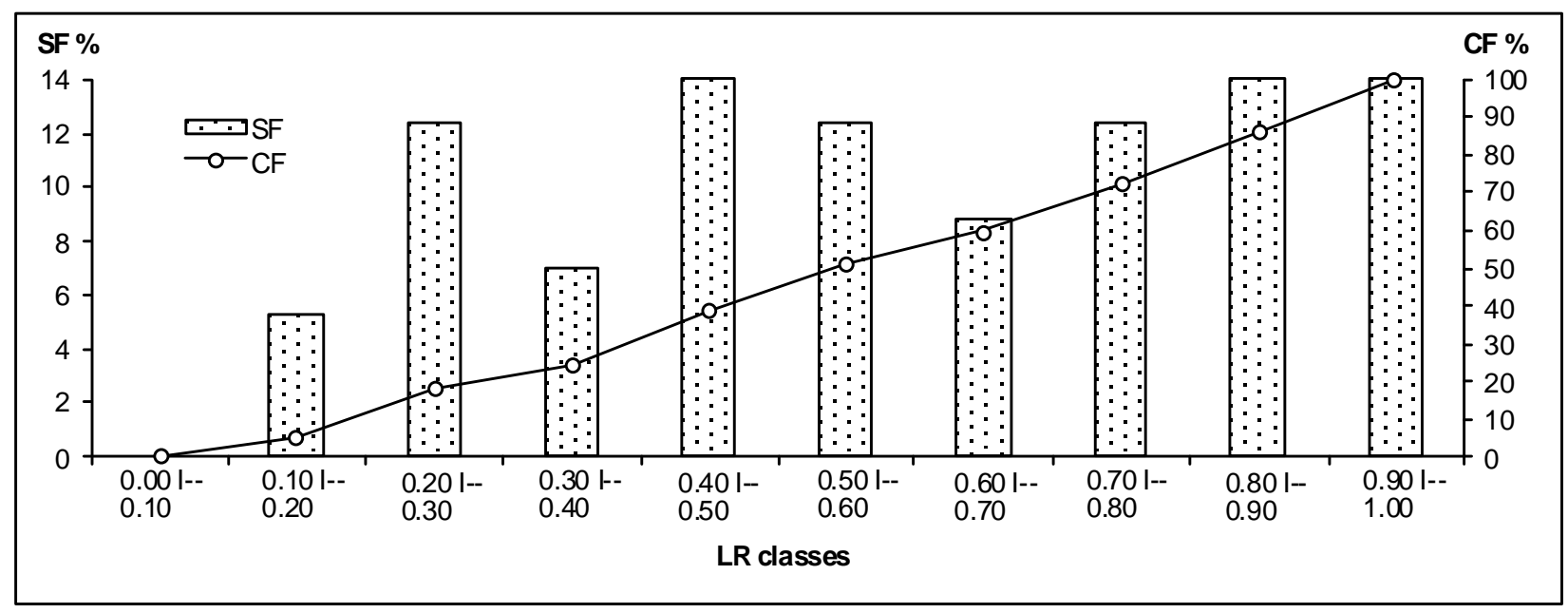

Figure 4. Single (SF) and cumulative (CF) frequency distributions of the percentage of species occupying each class of LR.

of large size individuals could be explained at the species level, possibly showing some adaptations at the populational level.

Subgroup A2 - 10 species whose LR was between 0.40 and 0.80 . Adult individuals could also be found, but with a length not exceeding $80 \%$ of the maximum size of the species. Thus, the absence of large size individuals in the mangrove was also explicable at the specific level, although that was possibly enhanced by adaptations at the populational level.

In the group A, no species was found with LR below 0.40 . In that case, all individuals would be presumed to be juveniles or sub adult.
GROUP B - 11 large-sized species whose MAL was above $300 \mathrm{~mm}$ and below $750 \mathrm{~mm}$, and LR equal or superior to 0.40 and its maximum value decreasing gradually from 0.99 (for a $\mathrm{MAL}=301 \mathrm{~mm}$ ) to 0.40 (for a $\mathrm{MAL}=750 \mathrm{~mm}$ ). Thus, in the mangrove these individuals are never greater than $300 \mathrm{~mm}$, although they could be found there at the adult stage. The absence of specimen of great size can therefore be explained at the populational level.

GROUP C - 12 large-sized species, whose MAL was above $300 \mathrm{~mm}$ and LR below 0.40 for MAL up to $750 \mathrm{~mm}$, and its maximum value decreased gradually to 0.11 as MAL increased around $2700 \mathrm{~mm}$. That means that despite the potentially important size of these species, no specimen was found in the mangrove with a length superior to 
$300 \mathrm{~mm}$. Their reduced size can be explained at the ecophase level. Indeed they are essentially species having accomplished a trophic migration before going back to the sea after a growth period in the bay. For example, in this ecosystem where a rocky bottom is rare, the groupers do not have a large enough habitat at their disposal in which to stay for a long time. The other species of Mugilidae, Ariidae, Sciaenidae genera were caught in the sea at larger sizes. On the other hand, Centropomus undecimalis has been caught down the small rivers coming in the west part of the bay.

GROUP D - 11 large-sized species, whose MAL was situated between 301 and $2700 \mathrm{~mm}$ and LR having a threshold decreasing gradually from the mangrove all populations present large size individuals (size superior to $300 \mathrm{~mm}$ ), in perspective of their development phase. No level has been proposed, since individuals with very great size are also welcomed by the ecosystem.

Is important to note that the three other species left of those found in the literature, $C$. arenaceus, $S$. hispidus and $C$. spinosus in the region had a MOL inferior to $300 \mathrm{~mm}$. However, their position in one of the groups cited above stays unknown.

Only $19.3 \%$ of species (group D) were represented in the region by individuals whose length exceeded $300 \mathrm{~mm}$. The cause of the

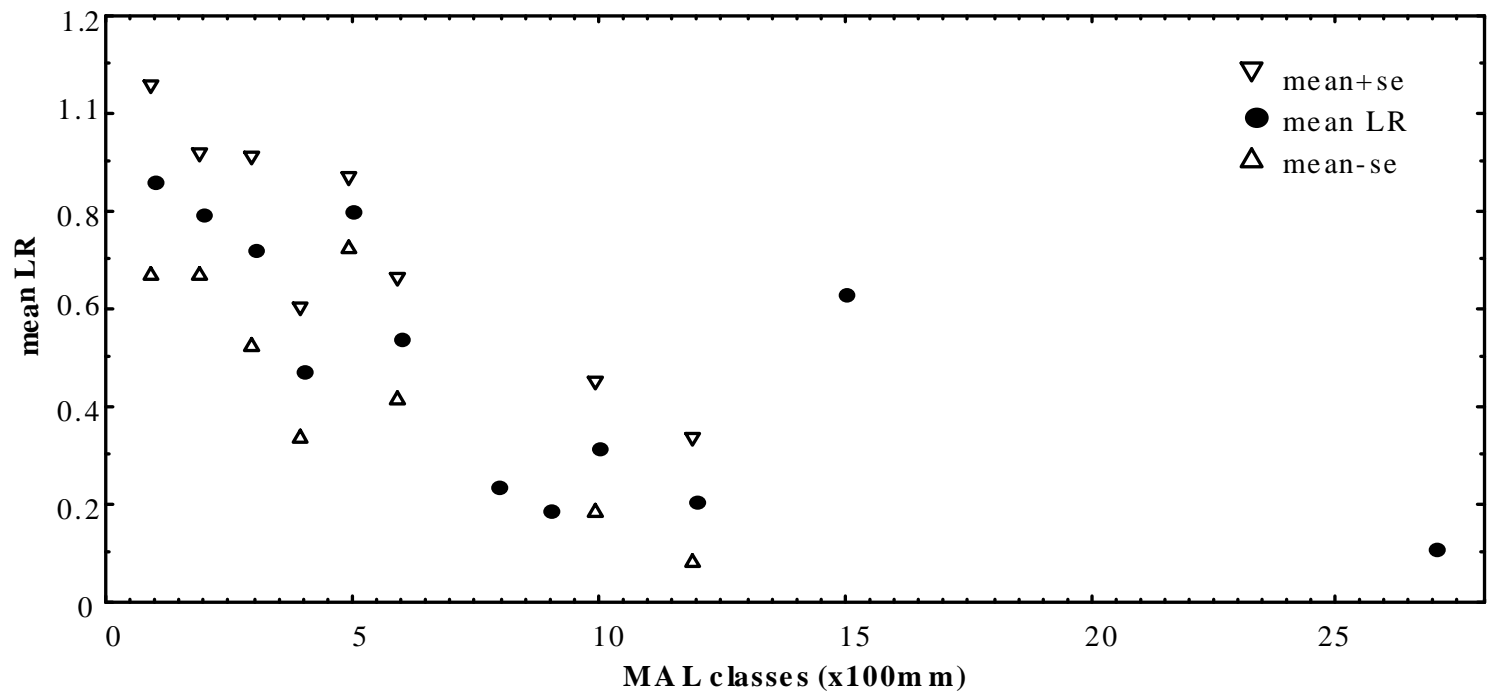

1.00 to 0.11 (it decreased as MAL increased). In

Figure 5. Distribution of mean LR values according to maximum available length (MAL) classes in mm.

absence of large size individuals was that $40.4 \%$ of populations belonged to species whose size was originally low (group A); for 19.3\% of populations, the absence was because apparently adults did not reach the same lengths in the mangrove that they could reach elsewhere (group B); and for $21.0 \%$ of populations, because individuals that visited the mangrove sector were only at juvenile or sub adult stages (group C).

\section{Indications for aquaculture}

Regarding the size, species with the greatest maximum length have been distributed in the region situated at the right of the graph in the Figure 6. These were those that presented generally a faster absolute growth than others (Legendre \& Albaret, 1991). On the other hand, in this group, those with the greatest LR demonstrated that adult individuals of some species also frequented the ecosystem. This observation has been an indication of their good adaptation in this area. As compared to the conjoint evolution of these two variables (Fig. 6 ), we propose therefore that preselection for breeding favors species classified in the group D. However, it is also necessary to consider some species of the group $\mathrm{C}$, particularly Centropomus undecimalis, which, even if they reached a relatively low maximum size, have characteristics likely to place them among species to be recommended for fish farming, which include: excellent appreciation by 
consumers, low cost, aquaculture techniques already tested (Table 2).

Finally, a more thorough examination of biological parameters, either biological, technological, or commercial order, suggested important parameters to guide the choice of priority species (Table 2). Thus, in addition to the fact of favoring species commercially appraised, and for which an aquaculture knowhow already exists, it is commendable to use those whose: reproduction is accomplished in the locality, fecundity is relatively important, and diet is not based on fishes (Trebaol, 1991). One will retain therefore, as priority species in this group of pre-selected species: $C$. parallelus, C. undecimalis, M. americanus and M. furnieri.

\section{DISCUSSION}

It has been observed that in the mangrove sector of Guaratuba Bay, the greater number of individuals in the populations could be found with a relatively important size, that attained at least $40 \%$ the maximum length known for the species. It did not mean that the assemblage has been rich in large size individuals, since populations whose effectives were the most numerous belonged to species whose MAL do not exceed $300 \mathrm{~mm}$, such as Pomadasys corvinaeformis, Eucinostomus argenteus, E. gula, E. melanopterus and Stellifer rastrifer (Chaves \& Bouchereau, 1999). In addition, whatever the animal population, under natural conditions, the juvenile and sub adults stages are numerically more represented than those of adults, which increases the relative abundance of

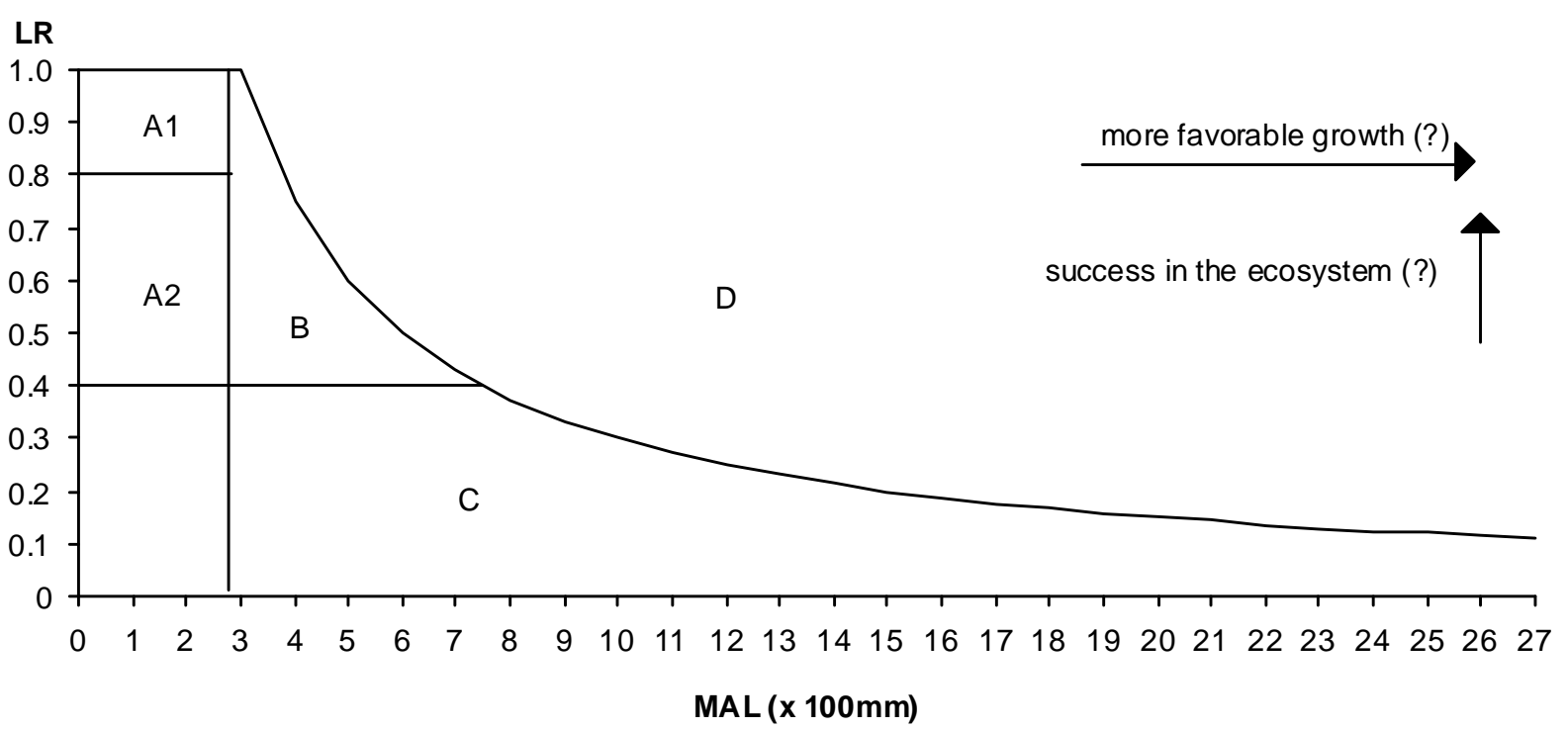

Figure 6. Graphic representation of the species groups places ("A" to "D"), classified according to LR values and maximum available length (MAL) in $\mathrm{mm}$.

the smallest individuals. Thus, even if the LR value 0.40 is not precise to standardize the beginning of the adult phase in all the populations, since it can vary according to the species and its geographical distribution area, the mangrove studied seems suitable for a large proportion of them to also attract to its bosom the most advanced stages of development.
The combination of LR and MAL results showed that the highest LR was associated with the smallest size species. Consequently, concerning the absolute sizes, although for the majority of species, individuals could reach a length superior to $300 \mathrm{~mm}$, a great part $(68 \%)$ of this was only represented in the mangrove by smaller sizes. Indeed, the LR value of these species, although superior to 0.40 , was not high enough so that the size of the greatest individuals exceeded $300 \mathrm{~mm}$. From such a 
situation, as a result hardly $19.3 \%$ of the 57 listed species showed in reality individuals with size greater than $300 \mathrm{~mm}$, which suggested that natural conditions of the ecosystem were not ideal to attract the large-sized species. Possible alterations of growth rates at the populational level, as well as size at first maturity, have not been evoked in the present study. Although insufficient to explain alone the weak proportion of species whose length of individuals exceeds $300 \mathrm{~mm}$, the reduction of growth can nevertheless play a very active role in the general size structure in the assemblage.

Do the populations of species with small size and high LR correspond to those having sedentary status in the system? In principle, the answer is negative since if populations of $G$. genidens, $S$. rastrifer, $C$. spilopterus, that are sedentary there, have a LR superior to 0.50, those of $P$. corvinaeformis, B. ronchus and $D$. rhombeus, that are not sedentary, presented also a high LR. In the population of $B$. ronchus, for example, LR reached 0.57 , adults only being present in the system during a certain period, and exit after the spawning period (Chaves, 1995). In the future, a comparative analysis of the distribution of LR values, as well as LR compared to MAL, calculated from fish assemblages from different regions (Southern America Bays, Western Africa estuaries, Occidental Mediterranean lagoons), could become a new parameter favoring the biological description of the semi enclosed ecosystems. Indeed, the curve obtained with RL index and MAL maximum available lengths is interesting as a descriptive tool of the ichtyofauna occupying a given ecosystem, and a comparative tool in space and time of the same ecosystem or between several ecosystems. This new ichtyological and environmental descriptor could be applied in the following fields: quality of an ecosystem with regard to its welcoming capacity, fish farming of new species, management as fishing regulation.

In the mangrove of Guaratuba, small size species are more numerous. They succeed to reach larger lengths, as compared to their known maximum length, than those of greater size. Among the former, and according to the criterion of possible or reached maximum size in the region, 12 pre-selected to realize tests for aquaculture in the region. Nevertheless, as emphasized by Legendre \& Albaret (1991), during the planning of a program for aquaculture, growth is only one of the factors to take into account in the analysis. In the present case, the totality of the parameters considered favors then only four species from the 12 preselected species: C. parallelus, C. undecimalis, $M$. americanus and $M$. furnieri. They represent a concret starting point for finer research on potentialities of fish farming in this Bay.

Table 2. Synoptic presentation of some attributes about 12 pre-selected species after size criteria; TE: knowledge of breeding techniques; CU: commercial utilization in the region and its level of utilization in the growing order " + " to " +++ ".

\begin{tabular}{|c|c|c|c|c|c|}
\hline \multirow[b]{2}{*}{ SPECIES } & \multirow[b]{2}{*}{ T E } & \multirow[b]{2}{*}{$\mathbf{C U}$} & \multicolumn{3}{|c|}{ BIOLOGICAL ASPECTS $^{1}$} \\
\hline & & & Reproduction & Diet & Note \\
\hline C. parallelus and & $\mathrm{Ff}^{*}$ & +++ & Frequent Matures & Carnivorous/Crustacean & Very considered for \\
\hline $\begin{array}{l}\text { C. undecimalis } \\
\text { C. leiarchus }\end{array}$ & No & +++ & Frequent Matures & Carnivorous/Ichtyophag. & $\begin{array}{c}\text { recreational fishing } \\
\text { - }\end{array}$ \\
\hline G. genidens & No & + & Spawning in Summer & Carnivorous/Crustacean & Low Fecundity \\
\hline G. ocellatus & No & No & $? ?$ & $? ?$ & - \\
\hline M. americanus & No & +++ & Frequent Matures & Carnivorous/Crustacean & High Fecundity \\
\hline M. furnieri & No & +++ & Frequent Matures & Carnivorous/Crustacean & High Fecundity \\
\hline$P$. saltatrix & No & +++ & $? ?$ & $? ?$ & - \\
\hline R. percellens & No & No & $? ?$ & $? ?$ & Low Fecundity \\
\hline S. luniscutis & No & + & $? ?$ & $? ?$ & - \\
\hline S. testudineus & No & No & \multicolumn{3}{|c|}{$\begin{array}{c}\text { Not available data for the region. Possible liver toxicity of Tetraodontiformes } \\
\text { discouraging its consumption (Legendre 1992) }\end{array}$} \\
\hline T. lepturus & No & + & Frequent Matures & Carnivorous/Ichtyophag & - \\
\hline
\end{tabular}

(*) Ff: Centropomidae fish farming technology developed by the State Fishery Institute, from São Paulo State and/or The Federal University of Santa Catarina (Brazil). ( ${ }^{1}$ ): Personal observations by Chaves, except G. genidens: Chaves (1994) and Chaves \& Vendel (1996). 


\section{RESUMO}

Realizou-se um inventário do comprimento máximo alcançado por 57 espécies de peixes no manguezal de Guaratuba, Brasil, objetivando caracterizar este ecossistema quanto ao tamanho dos indivíduos que acolhe. Para cada espécie, o comprimento máximo no manguezal foi comparado com aquele disponível na literatura, referente a outras populações da mesma espécie. Constatou-se que, na maioria das populações de Guaratuba, os indivíduos atingem pelo menos $40 \%$ do tamanho máximo conhecido para a espécie, embora em apenas 19,3\% das populações o comprimento ultrapasse $300 \mathrm{~mm}$ em valor absoluto. As outras espécies estão representadas no manguezal por indivíduos que (a) ou estão em fase inicial de desenvolvimento, ou (b) não alcançam o mesmo porte que aquele conhecido em outras populações. Neste manguezal, as espécies de maior tamanho relativo são normalmente as de menor porte. Propõe-se a utilização de um índice LR (comprimento máximo observado/ comprimento máximo conhecido) para auxiliar na descrição de assembléias de peixes e sua comparação entre diferentes regiões. As observações sobre o tamanho máximo possibilitam a pré-seleção de 12 espécies para testes de cultivo em Guaratuba, destacando, ao associar parâmetros biológicos, tecnológicos e comerciais, quatro delas como prioritárias: Centropomus parallelus, $C$. undecimalis, Menticirrhus americanus e Micropogonias furnieri.

\section{REFERENCES}

Albaret, J.-J. \& Legendre, M. (1985), Biologie et écologie des Mugilidae en lagune Ébrié (Côte d'Ivoire). Intérêt potentiel pour l'aquaculture lagunaire. Rev. Hydrobiol. Trop., 18(4):281-303.

Alvitres-Castillo, V.R. (1986), Estudo sobre a biologica e ciclo de vida de Menticirrhus americanus (Linneaeus, 1758) (UbatubaCananéia). Tese de Mestrado, Instituto Oceanográfico, Universidade de Sao Paulo: $150 \mathrm{p}$.
Borghetti, J.R. (1996), Estimativas da producáo pesqueira brasileira. Panorama $d a$ aqüicultura, Rio de Janeiro, 6(35):25-27.

Cervigón, F.; Cipriani, R.; Fisher, W.; Garibaldi, L.; Hendrickx, M.; Lemus, A.J.; Márques, R.; Poutiers, J.M.; Robaina, G.; Rodriguez, B. (1992), Guia de Campo de las Especies Comerciales Marinas y de Águas Salobres de la Costa Septentrional de Sur America. FAO, Roma, 513p.

Chaves, P.T.C. (1994), A incubação de ovos e larvas em Genidens genidens (Valenciennes) (Siluriformes, Ariidae) da Baía de Guaratuba, Paraná, Brasil. Revta bras. Zool., 11(4):641-648.

Chaves, P.T.C. (1995), Atividade reprodutiva de Bairdiella ronchus (Cuvier) (Pisces, Sciaenidae) na Baía de Guaratuba, Paraná, Brasil. Revta bras. Zool., 12(4):759-766.

Chaves, P.T.C. \& Bouchereau, J.-L. (1999), Biodiversité et dynamique des peuplements ichtyiques de la mangrove de Guaratuba, Brésil. Oceanologica Acta,22(3):353-364.

Chaves, P.T.C. \& Corrêa, M.F.M. (1998), Composição ictiofaunística da área de manguezal da Baía de Guaratuba, Estado do Paraná, Brasil (25`52'S;48³9'W). Revta bras. Zool., 15(1):195-202.

Chaves, P.T.C. \& Vendel, A.L. (1996), Aspectos da alimentação de Genidens genidens (Valenciennes) (Siluriformes, Ariidae) na Baía de Guaratuba, Paraná. Revta bras. Zool., 13 (3):669-675.

Coelho, J.A.P.; Graca-Lopes, E.; Rodrigues, E. S.; Puzzi, A. (1985), Relação pesocomprimento e tamanho de primeira maturação gonadal para o Sciaenidae Stellifer rastrifer (Jordan, 1889), no litoral do estado de Sao Paulo. Bolm. Inst. Pesca, São Paulo, 12(2):99-107.

Coelho, J.A.P.; Graca-Lopes, E.; Rodigues, E. S.; Puzzi, A. (1988), Aspectos biológicos e pesqueiros do sciaenidae Isopisthus parvipinnis (Cuvier, 1830), Teleostei, Perciformes, Sciaenidae, presente no rejeitado da pesca artesanal dirigida ao camarão sete-barbas. Bolm. Inst. Pesca, Sao Paulo, 19 (único):1-15.

Figueiredo, J.L. (1977), Manual de Peixes Marinhos do Sudeste do Brasil. I. Introdução. 
Cações, Raias e Quimeras. Museu de Zoologia, Universidade de São Paulo. São Paulo, 105p.

Figueiredo, J.L. \& Menezes, N.A. (1978), Manual de Peixes Marinhos do Sudeste do Brasil. II. Teleostei (1). Museu de Zoologia, Universidade de São Paulo. São Paulo, 110p.

Figueiredo, J.L. \& Menezes, N.A. (1980), Manual de Peixes Marinhos do Sudeste do Brasil. III. Teleostei (2). Museu de Zoologia, Universidade de São Paulo. São Paulo, 90p.

Frisoni G.; Guelorget O.; Perthuisot, J.-P. (1984), Diagnose écologique appliquée à la mise en valeur biologique des lagunes côtières méditerranéennes: aproche méthodologique; Biological diagnosis applied to biological development of maditerranean coastal lagoons: metodological approach. In Management of coastal lagoon fisheries; Aménagement des pêches dans les lagunes côtières; Stud. Rev/Etud. Rev. CGPM:39-95 (61), vol. 1:438p. (éd.) Kapetski, J.M. \& G. Lasserre (eds).

Guelorget, O. \& Perthuisot, J.-P. (1983), Le domaine paralique. expressions géologiques, biologiques et économiques du confinement. Presses de l'Ecole Normale Supérieure, Paris, 136p.

Haimovici, M. \& Umpierre, G. (1996), Varaiciones estacionales en la estructura poblacional de corvina blanca Micropogonias furnieri (Desmaret, 1823) en el extremo sur de Brasil. Atlantica, Rio Grande, 18:179-203.

Kiener, A. (1978), Ecologie, Physiologie et économie des eaux saumâtres. Collection de Biologie des Milieux Marins. Ed. Masson, Paris, 220p.

Legendre, M. (1992), Potentialités aquacoles des Cichlidae (Sarotherodon melanotheron, Tilapia guineensis) et Clariidae (Heterobranchus longifilis) autochtones des lagunes Ivoiriennes. Éditions de l'Orstom, Collection Travaux et Documents Microédités. Paris. 83pp. + annexes.

Legendre, M. \& Albaret, J.-J. (1991), Maximum observed length as an indicator of growth rate in tropical fishes. Aquaculture, 94:327341.

Menezes, N.A. \& Figueiredo, J.L. (1980), Manual de Peixes Marinhos do Sudeste do Brasil. IV. Teleostei (3). Museu de Zoologia, Universidade de São Paulo. São Paulo, 96p.

Menezes, N.A. \& Figueiredo, J.L. (1985), Manual de Peixes Marinhos do Sudeste do Brasil. V. Teleostei (4). Museu de Zoologia, Universidade de São Paulo. São Paulo, 105p.

Perez-Lizama, M.L.A. \& Vazzoler, A.E.A.M. (1993), Crescimento em peixes do Brasil: uma síntese comentada. UNIMAR, Maringá, 15 (suplemento):141-173.

Trebaol, L. (1991), Biologie et potentialités aquacoles du Carangidae Trachinotus teraia (Cuvier \& Valenciennes, 1832) en milieu lagunaire ivoirien. Éditions de l'ORSTOM, Collection Études et Thèses. Paris, 314p.

Appendix. Code of species quoted in Table 1.

\begin{tabular}{|c|c|c|}
\hline Species & Code & Species \\
\hline ACLI Achirus lineatus (Linné, 1758) & HACL & Harengula clupeola (Cuvier, 1829) \\
\hline ARRH Archosargus rhomboidalis (Linné, 1758) & HIRE & Hippocampus reidi Ginsburg, 1933 \\
\hline BARO Bairdiella ronchus (Cuvier, 1830) & ISPA & Isopisthus parvipinnis (Cuvier, 1830) \\
\hline BASO Bathygobius soporator (Valenciennes, 1837) & LALA & Lagocephalus laevigatus (Linné, 1766) \\
\hline CAHI Caranx hippos (Linné, 1766) & LYGR & Lycengraulis grossidens (Cuvier, 1829) \\
\hline CALA C. latus Agassiz, 1831 & MEAM & Menticirrhus americanus (Linné, 1758) \\
\hline CASP Cathorops spixii (Agassiz, 1829) & MELI & M. littoralis (Holbrook, 1860) \\
\hline CEED Cetengraulis edentulus (Cuvier, 1829) & MIFU & Micropogonias furnieri (Desmarest, 1823) \\
\hline CEPA Centropomus parallelus Poey, 1860 & MUCU & Mugil curema Valenciennes, 1836 \\
\hline CEUN C. undecimalis (Bloch, 1792) & MUGA & M. gaimardianus Desmarest, 1831 \\
\hline СНСН Chloroscombrus chrysurus (Linné, 1766) & NEBA & Netuma barba (Lacepède, 1803) \\
\hline CHFA Chaetodipterus faber (Broussonet, 1782) & OPOG & Opithonema oglinum (Lesueur, 1817) \\
\hline CHSP Chylomicterus spinosus (Linné, 1758) & ORRU & Orthorpistis ruber (Cuvier, 1830) \\
\hline CIAR Citharichthys arenaceus Evermann \& Marsh, 1900 & PABR & ıchurus brasiliensis (Steindachner, 1875) \\
\hline CISP C. spilopterus Gunther, 1862 & PEHA & Pellona harroweri (Fowler, 1917) \\
\hline
\end{tabular}


Appendix. Code of species quoted in Table 1 (Cont.).

\begin{tabular}{|c|c|c|}
\hline CYAC Cynoscion acoupa (Lacepède, 1802) & POCO & isys corvinaeformis (Steindachner, 1868) \\
\hline CYLE C. leiarchus (Cuvier, 1830) & POSA & Pomatomus saltatrix (Linné, 1766) \\
\hline DAVO Dactylopterus volitans (Linné, 1758) & PRPU & Prionotus punctatus (Bloch, 1797) \\
\hline DIRA Diplectrum radiale (Quoy \& Gaimard, 1824) & RHPE & Rhinobatos percellens (Walbaum, 1792) \\
\hline DIRH Diapterus rhombeus (Cuvier, 1829) & RYRA & Rypticus randalli Courtenay, 1967 \\
\hline EPIT Epinephelus itajara (Lichtenstein, 1822) & SCLU & $\begin{array}{l}\text { Sciadeichthys luniscutis (Valenciennes, } \\
1840 \text { ) }\end{array}$ \\
\hline EPNI E. niveatus (Valenciennes, 1828) & SEVO & Selene vomer (Linné, 1758) \\
\hline ETCR $E$. crossotus Jordan \& Gilbert, 1822 & SPTE & Sphoeroides testudineus (Linné, 1758) \\
\hline EUAR Eucinostomus argenteus Baird \& Girard, 1854 & STHI & Stephanolepis hispidus (Linné, 1766) \\
\hline EUBR Eugerres brasilianus (Cuvier, 1830) & STRA & Stellifer rastrifer (Jordan, 1889) \\
\hline EUGU Eucinostomus gula (Cuvier, 1830) & SYFO & Synodus foetens (Linné, 1766) \\
\hline EUME E. melanopterus (Bleeker, 1863) & SYTE & $\begin{array}{l}\text { Symphurus } \quad \text { tessellatus } \\
\text { Gaimard,1824) }\end{array}$ \\
\hline GEGE Genidens genidens (Valenciennes, 1839) & TRCA & Trachinotus carolinus (Linné, 1766) \\
\hline GELU Genyatremus luteus (Bloch, 1795) & TRLE & Trichiurus lepturus Linné, 1758 \\
\hline GYOC Gymnothorax ocellatus Agassiz, 1834 & TRPA & Trinectes paulistanus (Ribeiro, 1915) \\
\hline
\end{tabular}

